\title{
Experimental Design Applied to the Optimization and Partial Characterization of Pectin Liase from a Newly Isolated Penicillium brasilianum
}

\author{
Jamile Zeni, Jonaína Gomes, Éllin Ambroszini, Ana Paula Basso, Geciane Toniazzo and Eunice \\ Valduga" \\ Departamento de Engenharia de Alimentos; Universidade Regional Integrada; Erechim - RS - Brasil
}

\begin{abstract}
Penicillium brasilianum was previously isolated from tea and identified by molecular biology technique. A PlackettBurman design, followed by a complete second order design was used for the screening of most important factors and to maximize the pectin liase (PMGL) activity, respectively. The maximum PMGL activity by $P$. brasilianum achieved was $9.0 \mathrm{U} / \mathrm{mL}$ after $48 \mathrm{~h}$ of cultivation in a medium containing pectin $(33.0 \mathrm{~g} / \mathrm{L})$, yeast extract $(30.0 \mathrm{~g} / \mathrm{L})$ and potassium phosphate $(2.0 \mathrm{~g} / \mathrm{L})$ at $30^{\circ} \mathrm{C}$, with a stirring rate of $180 \mathrm{rpm}$, initial $\mathrm{pH} 5.5$ and $5 \times 10^{6} \mathrm{spores} / \mathrm{mL}$ inoculum size. The kinetic evaluation in terms of substrate consumption demonstrated that the maximum production of PMGL was at $72 \mathrm{~h}$, and $40 \%$ of the total organic carbon, $25 \%$ of the nitrogen, $88 \%$ of the magnesium, $13 \%$ of the potassium and $66 \%$ of the iron were consumed. The $\mathrm{pH}$ remained almost stable during the whole period of production (5.33 to 4.9). The partial characterization of the crude PMGL enzyme extract showed optimal pH and temperature of 5.5 and $37^{\circ} \mathrm{C}$, respectively.
\end{abstract}

Key words: Penicillium brasilianum, pectin liase, experimental design technique

\section{INTRODUCTION}

Pectic polymers (chain of 1,4-linked- $\alpha$-Dgalacturonic acid and methoxylated derivatives) are the major structural constituents of middle lamellae in plant cell wall. They play an important role in adhesion of adjacent cells together and have a great impact on the viscosity and turbidity of fruit juices (Lozano et al. 1990; Sandri et al. 2013). Pectinases are the group of enzymes involved in depolymerisation of the pectic polymers. The group of enzymes, which are involved in the degradation of "smooth region" (homogalacturonan) include deesterifying enzymes, i.e., pectin methyl esterases (PME, E.C. 3.1.1.11) and pectin acetyl esterase (PAE, E.C. 3.1.1.6) which remove methoxyl and acetyl residues of pectin producing polygalacturonic acid. The other subclass of homogalacturonan degrading group are broadly termed as depolymerases, which break the $\alpha$-1,4-linkages either by hydrolysis, i.e., polygalacturonases (PG, E.C. 3.2.1.15) or via transelimination mechanism, namely pectate liases (PL, E.C. 4.2.2.2) and pectin liases (PMGL, E.C. 4.2.2.10) (Whitaker et al. 1990).

Pectin liases are the only known pectinases capable of degrading highly esterified pectins (like those found in fruits) into small molecules via $\beta$ elimination mechanism without producing methanol, in contrast with the combination of PG and pectinesterases (PE, E.C. 3.1.1.1), which are normally found in the commercial products (Whitaker et al. 1990). This is important because

*Author for correspondence: veunice@uricer.edu.br 
methanol is toxic and may present health hazards. Methanol may be lost in vapour during juice concentration, but a different condition occurs in viscous materials (purees, baby foods, etc) or nonconcentrated juices where methanol is only partially released during pasteurization. In addition, the presence of undesirable enzymatic activity in commercial pectinases may be detrimental to aroma because they are responsible for producing unpleasant volatile off flavor (Targano et al. 1994). There are many reports of fruit juices clarification by pectin liases (Mantovani et al. 2005; Yadav et al. 2008; Kant et al. 2013; Wang et al. 2013). The alkaline pectinase are inappropriate to be used in the food industries due to acidic $\mathrm{pH}$ of fruit juices. However, they have a very high demand in the textile industries. They are used for retting of plant fibers such as ramie, sunn hemp, jute, flax and hemp (Cao et al. 1992; Kapoor et al. 2001).

Pectinases are biotechnologically important because they have potential applications in the clarification of fruit juices, retting of natural fibers (ramie, hemp, flax, bast), treatment of pectic waste water, coffee and tea leaf fermentation, oil extraction, virus purification, etc (Alkorta et al. 1998; Hoondal et al. 2002). Pectin liases are the only enzymes capable of depolymerising highly esterified pectin into small molecules without prior action of other enzymes (Delgado et al. 1992). PMGLs cleave pectin by $\beta$-elimination mechanism that results in the formation of 4,5-unsaturated oligogalacturonates without affecting the ester content of the polymer chain, which is responsible for specific aroma of fruits (Targano et al. 1994). Since new applications for pectin liases are emerging, the demands for production of these enzymes are increasing (Satyanarayana et al. 2005).

Like all pectinases, PMGL is also highly inducible enzymes even though there are reports of its considerable production in the absence of its natural inducer. PMGLs are mainly produced by fungi such as Aspergillus, Penicillium and Fusarium but there are a few reports on bacterial and yeast PMGL (Whitaker 1990; Fawole and Odunfa 2003; Gonçalves et al. 2012). In this context, the objective of this study was to evaluate the PMGL production by a newly isolated strain of $P$. brasilianum using submerged fermentation. After the media optimization, a kinetic evaluation was carried out and the enzyme was characterized in terms of optimum $\mathrm{pH}$.

\section{MATERIALS AND METHODS}

\section{Microorganism and growth conditions}

The microorganism used in the present study was previously isolated from tea, which was identified by molecular biology technique. After incubation in Potato Dextrose (PD) medium at $28^{\circ} \mathrm{C}$ for $3-$ 4 days, a protocol was used for the extraction of yeast genomic DNA using liquid nitrogen for cell disruption (Fernandes-salomão et al. 1996), followed by DNA quantification using a spectrophotometer model NanoDrop, ND-1000 (NanoDrop Technologies). The microorganism was identified as Penicillium brasilianum. The culture was on Potato Dextrose Agar (PDA) slant medium containing $(\mathrm{g} / \mathrm{L})$ malt extract 10.0 , yeast extract 4.0 , glucose 4.0 and agar 20 and incubated at $30^{\circ} \mathrm{C}$ for one week. Stock cultures were prepared with $20 \mathrm{wt} \%$ glycerol water and stored at $-80^{\circ} \mathrm{C}$ (MDF - U3086S - Sanyo). The harvesting of the spores from the slants was done using $5.0 \mathrm{~mL}$ of Tween $80-$ water $(0.02 \%)$. The spore suspension was collected in sterile falcon tube and stored at $4^{\circ} \mathrm{C}$ until the use. The concentration of the suspension was adjusted to $5.10^{6}$ spores per $\mathrm{mL}$.

\section{Pectin liase bioproduction}

For studying the effects of the composition of the culture medium and operating conditions of the bioproduction pectin liase Plackett-Burman Design was used; the independent variables studied were: pectin $(2.0-22.0 \mathrm{~g} / \mathrm{L})$, L-asparagine $(0-4.0 \mathrm{~g} / \mathrm{L})$, yeast extract $(0-20.0 \mathrm{~g} / \mathrm{L})$, iron sulphate II $(0-0.02 \mathrm{~g} / \mathrm{L})$, potassium phosphate $(0$ $-4.0 \mathrm{~g} / \mathrm{L})$ and magnesium sulfate $(0-1.0 \mathrm{~g} / \mathrm{L})$. Fixed variables were $30^{\circ} \mathrm{C}, 180 \mathrm{rpm}, \mathrm{pH} 5.5$ and $5 \times 10^{6}$ spores $/ \mathrm{mL}$. This was followed by a $2^{3}$ factorial design study comprising the variables: pectin $(11.0$ - 33.0 g/L $)$, yeast extract $(10.0$ $30.0 \mathrm{~g} / \mathrm{L})$, potassium phosphate $(2.0-4.0 \mathrm{~g} / \mathrm{L})$, while maintaining the fixed temperature $\left(30^{\circ} \mathrm{C}\right)$, agitation (180 rpm), $\mathrm{pH}(5.5)$ and time (48 h).

\section{Kinetic evaluation}

The kinetics of substrate consumption (total nitrogen, potassium, magnesium and total organic carbon - TOC), cell mass, $\mathrm{pH}$ evolution and PMGL production were followed by periodic sampling of the in the maximization condition $(33.0 \mathrm{~g} / \mathrm{L}$ of pectin, $30.0 \mathrm{~g} / \mathrm{L}$ yeast extract, $2.0 \mathrm{~g} / \mathrm{L}$ of potassium phosphate, $180 \mathrm{rpm}, 30^{\circ} \mathrm{C}, \mathrm{pH} 5.5$ and $5 \times 10^{6}$ spores $/ \mathrm{mL}$ ). 


\section{Partial characterization of crude enzymatic extracts}

To determine the optimum values of temperature and $\mathrm{pH}$ in terms of enzyme activity for $P$. brasilianum, a central composite rotatable design (CCRD) $2^{2}$ was accomplished using the enzymatic extract. The studied range for $\mathrm{pH}$ was from $3.0-$ 6.0 and temperature was from $30-80^{\circ} \mathrm{C}$. The temperature stability of the enzymatic extract was determined by enzyme incubation at a fixed $\mathrm{pH}$ (5.5) and different temperatures: $30-70^{\circ} \mathrm{C}$. The $\mathrm{pH}$ stability was determined by incubating the enzyme extract obtained at $40^{\circ} \mathrm{C}$ at the following $\mathrm{pH}: 3.0$ - 8.0. The samples were withdrawn at regular time intervals.

\section{Analytical determinations}

Pectin liase (PMGL) activity: The pectin liase activity was determined using the method described by Pitt (1988). One unit of enzyme activity was defined as the amount of enzyme, which resulted a change in absorbance of 0.01 at $550 \mathrm{~nm}$ under the assay conditions.

$p H$ : The $\mathrm{pH}$ was monitored using a potentiometer (DMPH-2, Digimed), after calibration with standard solutions $\mathrm{pH} 4.0$ and 7.0.

Total organic carbon (TOC): The total organic carbon (TOC) content was determined by the method of oxidation by catalytic combustion at $680^{\circ} \mathrm{C}$ and detection by infrared using a Shimadzu model TOC-VCSH analyzer (AOAC 1995).

Mineral compounds: Macro ( $\mathrm{Mg}$ and $\mathrm{Mn}$ ) and micronutrients ( $\mathrm{Fe}$ and $\mathrm{K}$ ) were determined by flame atomic absor ption spectrometry - FAAS (Varian Spectra AA-55), following the methodology described by AOAC (1995). Hollow cathode lamps of $\mathrm{Mg}$ and $\mathrm{Fe}$ were used as radiation source. The elements were measured in optimized operation conditions by FAAS in flame of air/acetylene or nitrous oxide/acetylene. The readings of $\mathrm{Mg}, \mathrm{Mn}, \mathrm{Fe}$ and $\mathrm{K}$ were performed by FAAS in absorption mode. To eliminate the possible interferences in the determination of $\mathrm{Mg}$ content, lanthanum chloride was added to the samples and to the standard solutions at a proportion of $1 \%(\mathrm{w} / \mathrm{v})$. For the determination of the minerals contents in the samples, calibration curves of standard solutions were used. The nitrogen content was determined by the Kjedahl method (VELP DK-20 e UDK-126D), following the methodology of AOAC (1995).

\section{Statistical Analysis}

The statistical analysis related to the estimated effects of each variable and process optimization was performed using the global error and the relative standard deviation between the experimental and predicted data. The other results were treated by analysis of variance (ANOVA), followed by Tukey's. All the analysis were performed using the software Statistica version 6.0 (Statsoft Inc, USA).

\section{RESULTS AND DISCUSSION}

\section{Pectin liase (PMGL) bioproduction}

Table 1 presents the matrix of a Plackett-Burman design with encoded values (actual) of the independent variables studied and the response in terms of pectin liase activity (PMGL). The maximum activity of pectin liase was obtained in run 5 at a central point with an activity of approximately $6.81 \mathrm{U} / \mathrm{mL}$, when the cultivation medium contained $22.0 \mathrm{~g} / \mathrm{L}$ pectin, $4.0 \mathrm{~g} / \mathrm{L} \mathrm{L}$ asparagine, $1.0 \mathrm{~g} / \mathrm{L}$ magnesium sulfate, and $4.0 \mathrm{~g} / \mathrm{L}$ potassium phosphate, without the addition of yeast extract and iron sulphate (II).

Figure 1 shows a Pareto chart with the estimated effects of the variables studied in the PlackettBurman design. Evidently pectin, yeast extract and potassium phosphate had significant $(\mathrm{p}<0.05)$ positive effects, which meant that when the concentration and/or range of this variable increased from level -1 to +1 , which might increase enzyme activity. However, L-asparagine had a significant $(\mathrm{p}<0.05)$ negative effect; therefore, as at level -1 , the concentration was zero, this variable was excluded from the process.

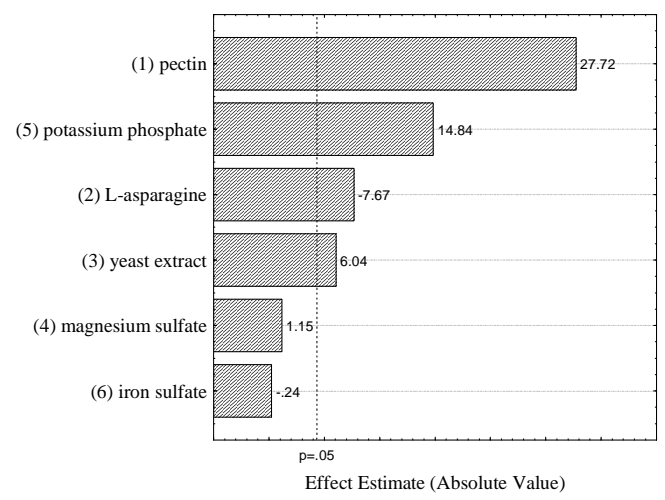

Figure 1 - Pareto Chart with the estimated effect (absolute value) of the variables tested in the experimental design of type PlackettBurman, for the production of pectin liase. 
Table 1 - Matrix of planning type Plackett-Burman (real and coded values) with the response in activity of pectin liase (PMGL) and $\mathrm{pH}$.

\begin{tabular}{|c|c|c|c|c|c|c|c|c|}
\hline \multirow[b]{2}{*}{ Runs } & \multicolumn{6}{|c|}{ Independent variables * } & \multicolumn{2}{|c|}{ Responses } \\
\hline & $\mathbf{X}_{1}$ & $\mathbf{X}_{2}$ & $\mathbf{X}_{\mathbf{3}}$ & $\mathbf{X}_{4}$ & $\mathbf{X}_{5}$ & $\mathrm{X}_{6}$ & PMGL (U/mL) & pH \\
\hline 1 & $1(22)$ & $-1(0)$ & $1(20)$ & $-1(0)$ & $-1(0)$ & $-1(0)$ & 5.97 & 5.07 \\
\hline 2 & $1(22)$ & $1(4)$ & $-1(0)$ & $1(1)$ & $-1(0)$ & $-1(0)$ & 2.36 & 6.95 \\
\hline 3 & $-1(2)$ & $1(4)$ & $1(20)$ & $-1(0)$ & $1(4)$ & $-1(0)$ & 2.22 & 6.85 \\
\hline 4 & $1(22)$ & $-1(0)$ & $1(20)$ & $1(1)$ & $-1(0)$ & $1(0.02)$ & 5.19 & 5.51 \\
\hline 5 & $1(22)$ & $1(4)$ & $-1(0)$ & $1(1)$ & $1(4)$ & $-1(0)$ & 6.81 & 4.7 \\
\hline 6 & $1(22)$ & $1(4)$ & $1(20)$ & $-1(0)$ & $1(4)$ & $1(0.02)$ & 5.70 & 5.63 \\
\hline 7 & $-1(2)$ & $1(4)$ & $1(20)$ & $1(1)$ & $-1(0)$ & $1(0.02)$ & 1.31 & 7.36 \\
\hline 8 & $-1(2)$ & $-1(0)$ & $1(20)$ & $1(1)$ & $1(4)$ & $-1(0)$ & 3.45 & 6.27 \\
\hline 9 & $-1(2)$ & $-1(0)$ & $-1(0)$ & $1(1)$ & $1(4)$ & $1(0.02)$ & 2.80 & 4.34 \\
\hline 10 & $1(22)$ & $-1(0)$ & $-1(0)$ & $-1(0)$ & $1(4)$ & $1(0.02)$ & 6.31 & 4.36 \\
\hline 11 & $-1(2)$ & $1(4)$ & $-1(0)$ & $-1(0)$ & $-1(0)$ & $1(0.02)$ & 0.07 & 4.53 \\
\hline 12 & $-1(2)$ & $-1(0)$ & $-1(0)$ & $-1(0)$ & $-1(0)$ & $-1(0)$ & 0.76 & 4.2 \\
\hline 13 & $0(11)$ & $0(2)$ & $0(10)$ & $0(0.5)$ & $0(2)$ & $0(0.01)$ & 6.86 & 6.26 \\
\hline 14 & $0(11)$ & $0(2)$ & $0(10)$ & $0(0.5)$ & $0(2)$ & $0(0.01)$ & 6.55 & 6.21 \\
\hline 15 & $0(11)$ & $0(2)$ & $0(10)$ & $0(0.5)$ & $0(2)$ & $0(0.01)$ & 6.99 & 6.54 \\
\hline
\end{tabular}

$\mathrm{X}_{1}=$ Pectin $(\mathrm{g} / \mathrm{L}), \mathrm{X}_{2}=$ L-asparagine $(\mathrm{g} / \mathrm{L}), \mathrm{X}_{3}=$ yeast extract $(\mathrm{g} / \mathrm{L}), \mathrm{X}_{4}=$ magnesium sulphate $(\mathrm{g} / \mathrm{L}), \mathrm{X}_{5}=$ potassium phosphate $(\mathrm{g} / \mathrm{L}), \mathrm{X}_{6}=$ iron sulphate $\mathrm{II}(\mathrm{g} / \mathrm{L})$; independent variables fixed: $180 \mathrm{rpm}, 30^{\circ} \mathrm{C}, 48 \mathrm{~h}, \mathrm{pH}_{\text {inicial }} 5.5$ and $5 \times 10^{6}$ spores $/ \mathrm{mL}$.

Based on the above results, a $2^{3}$ factorial design was carried out. The results presented in Table 2 showed that the maximum activity of PMGL was $7.07 \mathrm{U} / \mathrm{mL}$ (run 4) in a culture medium composed $33.0 \mathrm{~g} / \mathrm{L}$ of citrus pectin, $30.0 \mathrm{~g} / \mathrm{L}$ of yeast extract and $2.0 \mathrm{~g} / \mathrm{L}$ of potassium phosphate under conditions of $180 \mathrm{rpm}, 30^{\circ} \mathrm{C}, 48 \mathrm{~h}$ and $\mathrm{pH}_{\text {initial }}$ 5.5. Equation 1 shows the first order model that describes the activity of PMGL as a function of the variable pectin within the range studied. The model was validated by the analysis of variance, where a correlation coefficient of 0.95 was obtained. The calculated $\mathrm{F}$ value was 1.46 times higher than the value listed in statistical tables, which allowed the construction of the contour curve (Fig. 2), demonstrating that maximum production of PMGL was in a range of pectin concentration exceeding $22 \mathrm{~g} / \mathrm{L}$ and in the range 20.0- $30.0 \mathrm{~g} / \mathrm{L}$ of yeast extract.

$$
\mathrm{PMGL}=5.862+1.195 \mathrm{X}_{1}
$$

Where PMGL is the activity of pectin liase $(\mathrm{U} / \mathrm{mL})$ and $\mathrm{X}_{1}$ is the pectin concentration $(\mathrm{g} / \mathrm{L})$.

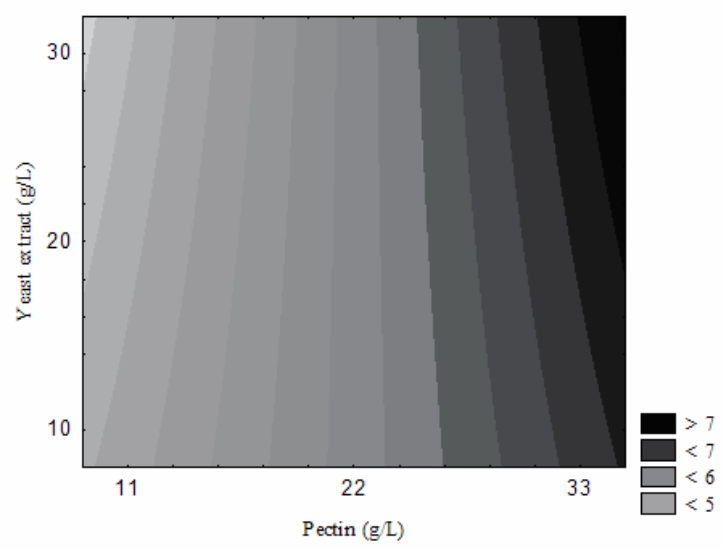

Figure 2 - Contour curve for the activity of PMGL as a function of pectin versus yeast extract.

Table 2 - Matrix of $2^{3}$ factorial design and response in production of pectin liase (PMGL) and $\mathrm{pH}$.

\begin{tabular}{cccccc}
\hline \multirow{2}{*}{ Runs } & \multicolumn{3}{c}{ Independent variables } & \multicolumn{2}{c}{ Responses } \\
\cline { 2 - 6 } & $\mathbf{X}_{\mathbf{1}}$ & $\mathbf{X}_{\mathbf{3}}$ & $\mathbf{X}_{\mathbf{5}}$ & $\mathbf{P M G L}(\mathbf{U} / \mathbf{m L})$ & $\mathbf{p H}$ \\
\hline 1 & $-1(11)$ & $-1(10)$ & $-1(2)$ & 6.08 & 5.51 \\
2 & $1(33)$ & $-1(10)$ & $-1(2)$ & 6.86 & 4.80 \\
3 & $-1(11)$ & $1(30)$ & $-1(2)$ & 4.61 & 5.59 \\
4 & $1(33)$ & $1(30)$ & $-1(2)$ & 7.07 & 4.89 \\
5 & $-1(11)$ & $-1(10)$ & $1(6)$ & 2.75 & 5.02 \\
6 & $1(33)$ & $-1(10)$ & $1(6)$ & 6.01 & 5.42 \\
7 & $-1(11)$ & $1(30)$ & $1(6)$ & 3.48 & 5.47 \\
8 & $1(33)$ & $1(30)$ & $1(6)$ & 6.53 & 4.92 \\
9 & $0(22)$ & $0(20)$ & $0(4)$ & 6.36 & 4.92 \\
10 & $0(22)$ & $0(20)$ & $0(4)$ & 5.54 & 4.89 \\
11 & $0(22)$ & $0(20)$ & $0(4)$ & 6.28 & 4.91 \\
\hline
\end{tabular}

$* \mathrm{X}_{1}=$ pectin $(\mathrm{g} / \mathrm{L}), \mathrm{X}_{3}=$ yeast extract $(\mathrm{g} / \mathrm{L}), \mathrm{X}_{5}=$ potassium phosphate $(\mathrm{g} / \mathrm{L})$. Independent variables fixed: $180 \mathrm{rpm}, 30^{\circ} \mathrm{C}, 48 \mathrm{~h}$ and $\mathrm{pH}_{\text {inicial }} 5.5$. 
In agreement with the results obtained in the $2^{3}$ factorial design where only the variable pectin had a significant effect $(\mathrm{p}<0.05)$, an experiment was carried out in triplicate by varying the concentration of pectin between 33.0, 40.0 and $45.0 \mathrm{~g} / \mathrm{L}$ and keeping the concentrations of yeast extract $(30.0 \mathrm{~g} / \mathrm{L})$ and potassium phosphate $(2.0 \mathrm{~g} / \mathrm{L})$ at $180 \mathrm{rpm}, 30^{\circ} \mathrm{C}, 48 \mathrm{~h}$ and $\mathrm{pH}_{\text {initial }} 5.5$. The maximum production of PMGL was $6.69 \mathrm{U} / \mathrm{mL}$ at a citrus pectin concentration of $33.0 \mathrm{~g} / \mathrm{L}$. At 40.0 and $45.0 \mathrm{~g} / \mathrm{L}$ citrus pectin, there was a significant reduction in the activity, indicating that an increase in the concentration of citrus pectin could inhibit the production of this enzyme due to excess substrate, which also might make the medium viscous and decreased transfer of oxygen.

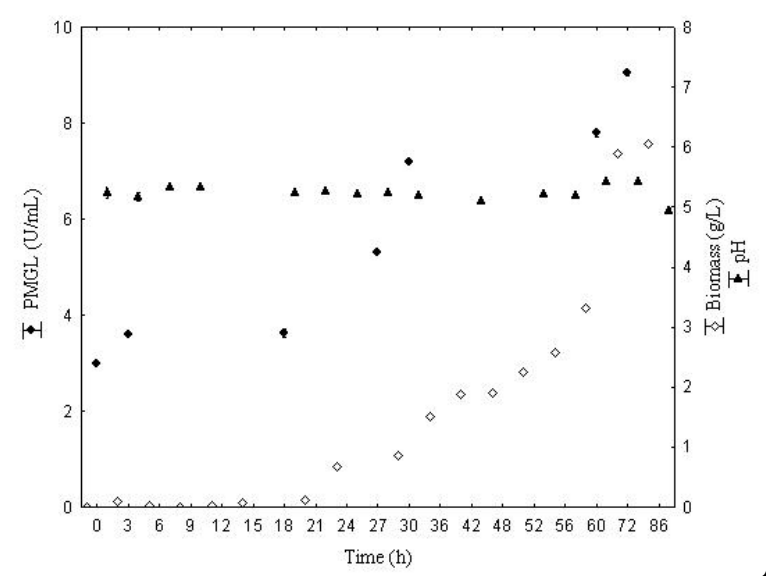

A

\section{Kinetic evaluation}

Figures $3 \mathrm{~A}$ and $3 \mathrm{~B}$ present the kinetic evaluation in terms of substrate consumption (total nitrogen, potassium, magnesium and total organic carbon) and $\mathrm{pH}$ evolution, biomass and pectin liase production in the maximized condition $(33.0 \mathrm{~g} / \mathrm{L}$ citrus pectin, $30.0 \mathrm{~g} / \mathrm{L}$ yeast extract, and $2.0 \mathrm{~g} / \mathrm{L}$ potassium phosphate at $180 \mathrm{rpm}, 30^{\circ} \mathrm{C}$ and $\mathrm{pH}_{\text {initial }}$ $5.5)$ as a function of time, respectively.

Figure 3A showed that the maximum PMGL activity $(9.0 \mathrm{U} / \mathrm{mL})$ was obtained after $72 \mathrm{~h}$ of culture incubation; during the same period, the microorganism reached the end of its exponential growth phase.

Figure 3 - kinetic Study of bioproduction of PMGL depending on the activity, production of biomass and $\mathrm{pH}$ by time (A) and on the basis of consumption of carbon, nitrogen and minerals by time $(\mathrm{B})$, respectively.

The enzymatic activity of PMGL $(9.0 \mathrm{U} / \mathrm{mL})$ was similar to that reported by Santos et al. (2008), who studied the production and characterization of pectinolytic enzymes produced by $P$. oxalicum using agro-industrial waste and found that when the medium contained orange peel $(1 \%)$, higher production of pectin liase $(9.59 \mathrm{U} / \mathrm{mL})$ occurred after $96 \mathrm{~h}$ of cultivation at $170 \mathrm{rpm}$ and $28^{\circ} \mathrm{C}$. Camargo et al. (2005) studied the production of extracellular pectin liase from Aspergillus sp. isolated from the soil, half submerged in medium containing residue of orange and citrus pectin as sole source of carbon; after $68 \mathrm{~h}$, the activity was $11.3 \mathrm{U} / \mathrm{mL}$. The $\mathrm{pH}$ (Fig. 3A) was almost stable during the whole period of production (5.33 to 4.9).
Figure 3B showed that there was a slow consumption of organic carbon up to $27 \mathrm{~h}$, afterwards a gradual decrease until $86 \mathrm{~h}$ was observed with a total consumption of $40 \%$ (final TOC $136 \mathrm{mg} / \mathrm{L}$ ). A similar behavior was observed for the iron content, with a total consumption of $66 \%$ (Fe $11.21 \mathrm{mg} / \mathrm{L})$. However, the assimilation of nitrogen was slow and gradual throughout the production, with a total consumption of $25 \%$. Regarding potassium, the decrease was higher in the first $6 \mathrm{~h}$ of the production (from 2,900 to $2,600 \mathrm{mg} / \mathrm{L}$ ) and after this period, it remained almost constant $(2,600$ to $2,520 \mathrm{mg} / \mathrm{L})$. The same behavior was observed for the magnesium, but in the first nine hours, the consumption was $60 \%$ and after $86 \mathrm{~h}$, its assimilation was $88 \%$. 


\section{Partial characterization of pectin liase (PMGL) crude extract}

Effect of temperature and $\mathrm{pH}$ on crude enzymatic extracts activity

Table 3 shows the matrix of the full factorial design $2^{2}$ ( 3 central points) as well as the results of the enzymatic activity of pectin liase. The highest activity was $11.97 \mathrm{U} / \mathrm{mL}$ in run 2 at $\mathrm{pH} 5.5$ and $37^{\circ} \mathrm{C}$.

Table 3 - Matrix of the full factorial design $2^{2}$ (real and coded values) with the responses of and response in enzyme activity of pectin liase as a function of temperature and $\mathrm{pH}$.

\begin{tabular}{cccc}
\hline Runs & \multicolumn{2}{c}{ Independent variables* } & Pectin liase \\
\cline { 2 - 4 } & $\mathbf{p H}$ & Temperature $\left({ }^{\circ} \mathbf{C}\right)$ & $(\mathbf{U} / \mathbf{m L})$ \\
\hline 1 & $-1(3.4)$ & $-1(37)$ & 7.32 \\
2 & $1(5.5)$ & $-1(37)$ & 11.97 \\
3 & $-1(3.4)$ & $1(73)$ & 7.01 \\
4 & $1(5.5)$ & $1(73)$ & 10.85 \\
5 & $-1.41(3)$ & $0(55)$ & 7.20 \\
6 & $1.41(6)$ & $0(55)$ & 9.14 \\
7 & $0(4.5)$ & $-1.41(30)$ & 8.96 \\
8 & $0(4.5)$ & $1.41(80)$ & 7.84 \\
9 & $0(4.5)$ & $0(55)$ & 9.91 \\
10 & $0(4.5)$ & $0(55)$ & 10.44 \\
11 & $0(4.5)$ & $0(55)$ & 10.17 \\
\hline
\end{tabular}

Equation 2 showed the second order model that described the concentration of PMGL as a function of the analyzed variables (temperature and $\mathrm{pH}$ ), within the ranges studied. The model was validated by the analysis of variance, where a correlation coefficient of 0.88 was obtained and the calculated $F$ value was 1.41 times higher than the value listed in the statistical tables, allowed the construction of the contour curve (Fig. 4).

PMGL $=10.17+1.41 . \mathrm{pH}-0.63 .(\mathrm{T})^{2}$

Where PMGL is the activity of pectin liase $(\mathrm{U} / \mathrm{mL})$ and $\mathrm{T}$ is the temperature $\left({ }^{\circ} \mathrm{C}\right)$.

The maximum enzymatic activity of the crude extract occurred in the range of $\mathrm{pH} 4.5$ to 6.5 and 30 to $60^{\circ} \mathrm{C}$ (Fig. 4). Yadav et al. (2009) found that the $\mathrm{pH}$ and temperature optima for PMGL produced by several microorganisms varied from 5.0 to 10.5 and 32 to $60^{\circ} \mathrm{C}$, respectively, depending on the microorganism. Silva et al. (2002) studied the production of PMGL by a strain of $P$. viridicatum $\mathrm{RFC} 3$, which showed maximum activity at $\mathrm{pH} 10.5$ and $50^{\circ} \mathrm{C}$.

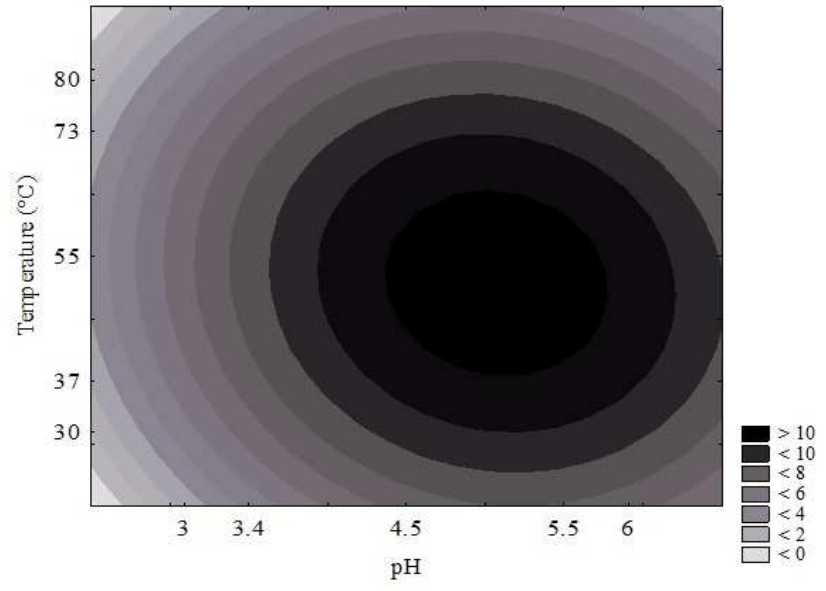

Figure 4 - Contour curve for the activity of PMGL as a function of temperature and $\mathrm{pH}$.

\section{Temperature stability of the crude enzymatic} extracts

Evaluation of the stability of the crude enzyme extract of PMGL was performed by incubating at different temperatures $\left(30,40,50,60\right.$ and $\left.70^{\circ} \mathrm{C}\right)$, and monitoring its behavior as a function of time (Fig. 5). The crude enzyme extract presented the highest stability at 30 and $40^{\circ} \mathrm{C}$, retaining 53 and $54 \%$ of its initial PGML activity after 2,300 and $2,100 \mathrm{~h}$ of storage, respectively. At 50, 60 and $70^{\circ} \mathrm{C}$, the behavior was similar, maintaining residual activity of about $50 \%$ to $1,370 \mathrm{~h}$. Busto et al. (2006) evaluated the stability of the commercial pectin liase, free and immobilized in support (sodium alginate) and found that at $40^{\circ} \mathrm{C}$ the free and immobilized enzyme retained 57 and $50 \%$ of the activity, respectively after $2.5 \mathrm{~h}$ incubation. The thermal stability was lower at higher temperatures, retaining only $7 \%$ activity after $2.5 \mathrm{~h}$ at $60^{\circ} \mathrm{C}$. In spite of this, $40^{\circ} \mathrm{C}$ is most frequently used in juice processing Minussi et al. (1998), evaluating the stability of PMGL from $P$. griseoroseum observed that the enzyme was stable up to $40^{\circ} \mathrm{C}$, but lost all its activity when maintained at $55^{\circ} \mathrm{C}$ during one hour. Silva et al. (2002) evaluated the stability of PMGL produced by $P$. viridicatum RFC3 and found higher thermal stability at $35^{\circ} \mathrm{C}$ for one hour.

\section{pH stability of the crude enzymatic extracts}

The stability of the crude PMGL enzyme extract to different $\mathrm{pH}$ was performed by monitoring the behavior as a function of time. The extract was incubated at $40^{\circ} \mathrm{C}$ at an initial $\mathrm{pH}$ of 4.89 and then its activity was evaluated at different $\mathrm{pH}(3.0,3.4$, 
4.5, 5.5, 6.0, 7.0 and 8.0). The results obtained are presented in Figure 6, which showed that the crude enzyme extract had maximum stability at $\mathrm{pH} 5.5$, retaining $54 \%$ of its initial activity after $1,500 \mathrm{~h}$ of storage. Silva et al. (2002) reported higher stability of PMGL from $P$. viridicatum $\mathrm{RFC} 3$ at acidic $\mathrm{pH}$.

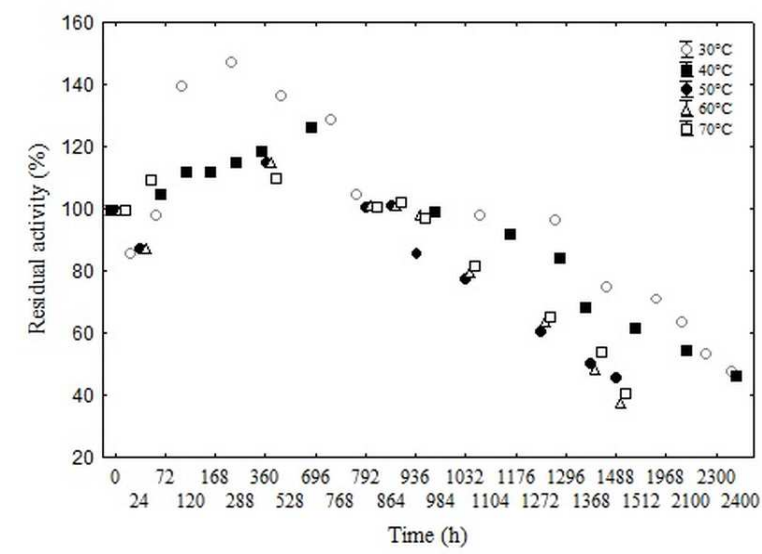

Figure 5 - Influence of temperatures of 30, 40, 50, 60 and $70^{\circ} \mathrm{C}$ on stability of the crude enzymatic extract obtained Penicillium brasilianum.

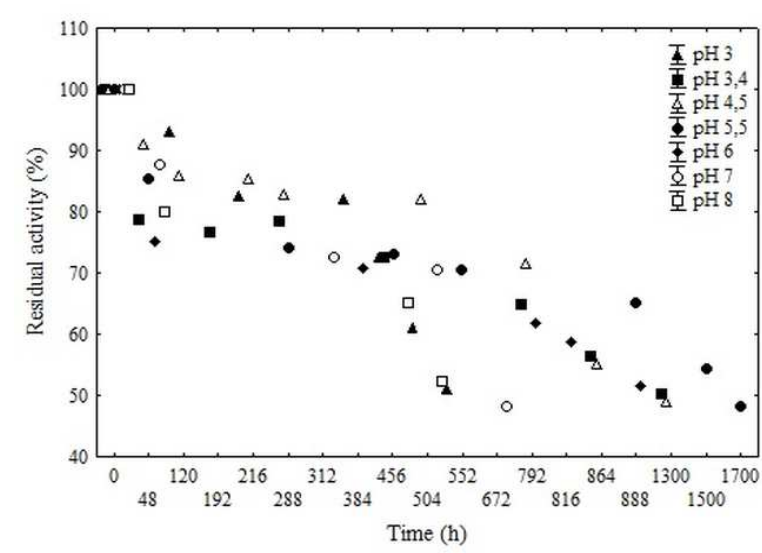

Figure 6 - Influence of $\mathrm{pH}$ on stability of the crude enzymatic extract obtained by Penicillium brasilianum.

\section{CONCLUSIONS}

The maximum production of pectin liase by $P$. brasillianum was $9.0 \mathrm{U} / \mathrm{mL}$ at $72 \mathrm{~h}$ with pectin concentration of $33.0 \mathrm{~g} / \mathrm{L}$, yeast extract $30.0 \mathrm{~g} / \mathrm{L}$ and potassium phosphate $2.0 \mathrm{~g} / \mathrm{L}$ at $30^{\circ} \mathrm{C}$, $180 \mathrm{rpm}$, initial $\mathrm{pH} 5.5$ and $5 \times 10^{6}$ spores $/ \mathrm{mL}$ inoculum size. Partial characterization of the crude enzyme extract showed $\mathrm{pH} 5.5$ and $37^{\circ} \mathrm{C}$ as optimal. The crude enzyme extract showed good stability at 30 and $40^{\circ} \mathrm{C}$ for 2,300 and $2,100 \mathrm{~h}$, and at $\mathrm{pH} 5.5$ for $1,500 \mathrm{~h}$.

\section{ACKNOWLEDGEMENTS}

The authors thank CNPq and CAPES for the financial support and scholarships.

\section{REFERENCES}

Alkorta I, Garbisu C, Liama, MJ, Serra JL. Industrial application of pectic enzymes: a review. Process Biochem. 1998; 33: 21-28.

Association of Official Analytical Chemists - AOAC. Official methods of analysis of the association of the analytical chemists, 16. ed. Washington, 1995.

Busto MD, García-Tramontín KE, Ortega N, PerezMateos M. Preparation and properties of an immobilized pectinlyase for the treatment of fruit juices. Bioresource Technol. 2006; 97: 1477-1483.

Camargo LA, Dentillo DB, Cardillo L, Gattás EAL. Utilization of orange bagasse in pectinases production by Aspergilllus sp. Alim Nutr. 2005; 16(2): 153-156.

Cao J, Zheng L, Chen S. Screening of pectinase producer from alkalophilic bacteria and study on its potential application in degumming of ramie. Enzyme Microb Technol. 1992; 14: 1013-1016.

Delgado L, Blanca AT, Huitron C, Aguilar G. Pectin liase from Aspergillus sp. CH-Y-1043. Appl Microbiol Biotechnol. 1992; 39: 515-519.

Fawole OB, Odunfa SA. Some factors affecting production of pectic enzymes by Aspergillus niger. Int Biodeterior Biodegrad. 2003; 52: 223-227.

Fernandes-salomão TM, Amorim ACR, Chaves-alves VM, Coelho JLC, Silva DO, Araújo EF. Isolation of pectinase hyperproducing mutants of. Penicillium expansum. Rev Microbiol. 1996; 27: 15-18.

Gonçalves DB, Teixeira JA, Bazzolli DMS, Queiroz MV, De Araújo EF. Use of response surface methodology to optimize production of pectinases by recombinant Penicillium griseoroseum T20. Biocatal Agric Biotechnol. 2012; 1: 140-146.

Hoondal GS, Tewari RP, Tewari R, Dahiya N, Beg QK. Microbiol alkaline pectinases and their industrial applications. A review. Appl Microbiol Biotechnol. 2002; 59: 409-418.

Kant S, Vohra A, Gupta R. Purification and physicochemical properties of polygalacturonase from Aspergillus niger MTCC 3323. Protein Expr Purif. 2013; 87: 11-16. 
Kapoor M, Beg QK, Bhushan B, Singh, K, Dadhich KS, Hoondal GS. Application of alkaline thermostable polygalacturonase from Bacillus sp. MG-ep-2 in degumming of ramie (Boehemeria nivea) and sunn hemp (Crotalaria juncea) bast fibers. Process Biochem. 2001; 6: 803-807.

Lozano P, Manjon A, Iborra JL, Galvez DM. Characteristics of the immobilized pectin liase activity from a commercial pectolytic enzyme preparation. Acta Biotechnol.1990; 10: 531-539.

Mantovani CF, Geimba MP, Brandelli A. Enzymatic clarification of fruit juices by fungal pectin liase. Food Biotechnol. 2005; 19: 173-181.

Minussi RC, Soraes-Ramos JRL, Coelho JLC, Silva DO. Sugar-cane juice induces pectin liase and polygalacturonase in Penicillium griseoroseum. Rev Microbiol. 1998; 29: 246-250.

Pitt M. Pectin liase from Phoma medicaginis var. pinodella. In: Methods Enzymol. 1988; 161: 350-354.

Sandri IG, Lorenzoni CMTL, Fontana RC, da Silveira MM. Use of pectinases produced by a new strain of Aspergillus niger for the enzymatic treatment of apple and blueberry juice. Food Sci Technol. 2013; 51: 469-475.

Santos SFM, Macedo GR, Silva FLH, Souza RLA, Pinto GAS. Application of response surface methodology in the study of the production and extraction of polygalacturonase. Quím Nov. 2008; 31: 1973-1978.

Satyanarayana NG, Kumar S. Microbial pectic transeliminases: a review. Biotechnol Lett. 2005; 27 . 451-458.
Silva D, Martins ES, Silva R, Gomes E. Pectinase production by Penicillium viridicatum RFC3 by solid state fermentation using agricultural wastes and agroindustrial by-products. Braz J Microbiol. 2002; 33(4): 318-324.

Targano VM, Pelosof AMR. Application of Doehlert design for water activity, $\mathrm{pH}$ and fermentation time, optimization for Aspergillus niger pectinolytic activity and production in solid state and submerged fermentations. Enzyme Microb Technol. 1994; 25: 411-419.

Wang B, Cheng F, Lu Y, Ge W, Zhang W, Yue B. Immobilization of pectinase from Penicillium oxalicum F67 ontomagnetic cornstarch microspheres: Characterization and applicationin juice production. $J$ Mol Catal B: Enzym. 2013; 97: 137-143.

Whitaker JR. Microbial pectolytic enzymes. In: Fogarty WM, Kelly CT, editors. Microbial enzymes and biotechnology. 2. ed., New York: Elsevier Appl Sci. 1990; 133-176.

Yadav S, Yadav PK, Yadav D, Yadav KDS. Pectin liase: A review. Process Biochem. 2009; 44: 1-10.

Yadav S, Yadav PK, Yadav D, Yadav KDS. Purification and characterization of an acidic pectin liase produced by Aspergillus ficuum strain MTCC 7591 suitable for clarification of fruit juices. Ann Microbiol. 2008; 58: 61-65. 